ADVANCE RESEARCH JOURNAL OF SOCIAL SCIENCE
$\begin{gathered}\text { RESEARCH } \\ \text { ARTICLE }\end{gathered}$ $\begin{array}{cc}\text { volume } 9 \mid \text { Issue } 1 \mid \text { June, } 2018 \mid 38-40 \text { a e ISSN-2231-6418 } \\ \text { DOI: 10.15740/HAS/ARJSS/9.1/38-40 } & \text { Visit us : www.researchjournal.co.in }\end{array}$

\title{
Coping pattern of rural drop out youth of Jorhat district
}

Mala Handique* and Krishna Baruah

AICRP-on Home Science, Department of Human Development and Family Studies, Faculty of Home Science, Assam Agricultural University, Jorhat (Assam) India

\section{ARTICLE INFO :}

$\begin{array}{lll}\text { Received } & : & 01.12 .2017 \\ \text { Revised } & : & 22.04 .2018 \\ \text { Accepted } & : & 08.05 .2018\end{array}$

\section{KEY WORDS :}

Coping, Approach, Avoidance, Dropout

\section{HOW TO CITE THIS ARTICLE :}

Handique, Mala and Baruah, Krishna (2018). Coping pattern of rural drop out youth of Jorhat district. Adv. Res. J. Soc. Sci., 9 (1) : 38-40, DOI: 10.15740/HAS/ ARJSS/9.1/38-40.

Copyright@2018 : Hind Agri -

Horticultural Society

*Author for correspondence

\begin{abstract}
The study was conducted in a village near Jorhat town. The objective of the study was to assess the coping pattern of rural drop-out youth. The sample comprised of thirty five numbers of youth age ranging from 17 to 24 years. Coping response inventory by Moos (1993) which measures both approach and avoidance coping was used in this research study. The results revealed that in all the dimensions of coping pattern the respondents fall under high and average category. None of the respondents fall in the low category of coping pattern.
\end{abstract}

